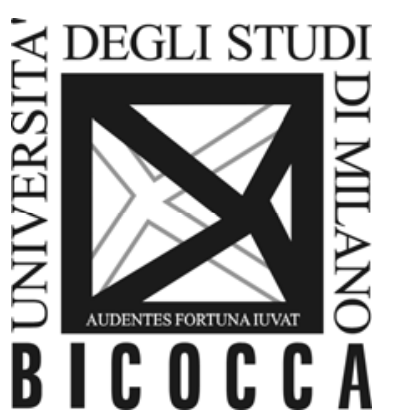

\author{
DEPARTMENT OF ECONOMICS, \\ MANAGEMENT AND STATISTICS \\ UNIVERSITY OF MILAN - BICOCCA
}

DEMS WORKING PAPER SERIES

The Italian Post-World War II Experience in Human Relations and Corporate Welfare

\author{
Valerio Varini
}

No. 329 - February 2016

Dipartimento di Economia, Metodi Quantitativi e Strategie di Impresa Università degli Studi di Milano - Bicocca

http://dems.unimib.it/ 


\title{
The Italian Post-World War II Experience in Human Relations and Corporate Welfare
}

\author{
Valerio Varini*
}

\begin{abstract}
The relevance of interventions in welfare and social security systems in the twentieth century has become the subject of extensive historical research. In particular from a prevalent focus on State intervention to a more in-depth historiographic reconsideration of the work performed by private institutions, including an important role played by industry. The focus of this paper is precisely the Corporate Welfare in the context of action after IIWW, by addressing the transformation in practices in terms of welfare and social security for workers, the essence of which is capable of revealing the participatory and communal nature of companies. In specific, I concentrate my attention on the relevance of the Human Relations in Italy and their effects on the Corporate Welfare. The paper examines some cases of HR as OM, Pirelli, Falck and Uniliver. Finally there is a specific attention on the job training of the "leader" and the "social worker of the factory".
\end{abstract}

Keywords: Human relations, welfare capitalism, firm.

JEL codes: N340 N940 ; L310 - L330

\footnotetext{
* Assistant Professor in Economic History and Business History, Department of Economics, Management and Statistics, Università degli studi Milano - Bicocca, Milano, Italy, Tel. +3902 64483024, Email: valerio.varini@unimib.it
} 
The relevance of interventions in welfare and social security systems in the twentieth century has become the subject of extensive historical research. Some of these (limited to the most recent), have affected both the public and private sectors ${ }^{1}$. In particular, one can note the broader horizon explored: from a prevalent focus on State intervention to a more in-depth historiographic reconsideration of the work performed by private institutions, including an important role played by industry $^{2}$. The focus is precisely in the context of action taken by the latter, by addressing the transformation in practices in terms of welfare and social security for workers, the essence of which is capable of revealing the participatory and communal nature of companies.

Since the nineteenth century, historiography has focused on the social work and welfare promoted by companies and, due to their prevalent personal and family configuration, labelled and incorporated them under "paternalism”. A term which has sparked huge debates regarding its nature and the objectives pursued. In this regard, it is useful to recall how broad and varied forms of paternalistic interventions in Britain's early industrialisation period generated a considerable amount of research on this matter. This originated in the 1980s in a heated interpretative dispute; a dispute which focused on the original motives and the interrelations between service providers in the dual role of the company and its owners, and the beneficiaries. ${ }^{3}$

According to some distinguished scholars, the turning point which marked the transformation of "paternalism" towards corporate welfare occurred following the expansion of the organisational dimension of companies culminating in managerial change ${ }^{4}$. This development was especially evident in the United States, where the welfare practiced by companies in the first half of the twentieth century was so widespread and intense that it had a long-term influence on public institutions' intervention in social spheres. This helped weaken the personal relationship between the employer and the welfare recipient, and was substituted by the administrative management of welfare known by different names such as capitalism, company, etc. The latter's differentiating aspect to traditional paternalism lay in the incorporation of the management of services provided to

\footnotetext{
${ }^{1}$ For brevity, reference is made to the recent volume P. Battilani - C. Benassi (eds.). Consumare il welfare. L'esperienza italiana del secondo Novecento, Il Mulino, Bologna 2013.

2 Reference is made to the recent synthesis in K. SLUYTERMAN, "Corporate Social Responsibility of Dutch Entrepreneurs in the 20th Century”, Enterprise \& Society, Vol. 12, June 2012: A. CARERA (ed.), Opere sociali e responsabilità d'impresa. Casi e temi nel Novecento, Vita \& Pensiero, Milan 2009; L. TREZZI - V. VARINI (eds.), Comunità di lavoro. Le opere sociali delle imprese e degli imprenditori tra Ottocento e Novecento, Guerini and Associates, Milan 2012.

${ }^{3}$ For a summary of the debate, see R. PRICE, The labour process and labour history, "Social History", I (January I 983); P. JOYCE, Labour, capital and compromise: a response to Richard Price, "Social History”, Vol. 9, No. 1 (Jan., 1984), pp. 67-76; R. PRICE, Conflict and co-operation: a reply to Patrick Joyce, "Social History”, IX, 2 (May 1984); P. JOYCE, Languages of reciprocity and conflict: a further response to Richard Price, "Social History", Vol. 9, 2 (May, 1984), pp. 225-231.

${ }^{4}$ As a useful comparison, see the British case in J. MELLING, Employers, Industrial Housing, and the Evolution old company Welfare Policies in Britain's Heavy Industry: West Scotland, 1870-1920, "International Review
} 
the surrounding community within the company's own organisational functions, with a corresponding reduction in the owner's decision-making powers.

After reaching its peak in the 1920s, corporate welfare in the United States underwent considerable downsizing due to economic stringency. This was caused by the Great Depression, which was followed by a problematic recovery in the years of the New Deal, hampered by regulations relating to industrial relations and union representatives ${ }^{5}$.

This downsizing was considered by some as the prelude to the depletion of "welfarism", understood as being the predominant tool used to reduce trade union membership, while other scholars have emphasised its permanence even post-World War II, though having changed in form. This leads to most recent years in which we are witnessing a renewed interest and an increase in the social action of companies, even more so with the downsizing of public intervention in these areas. ${ }^{6}$

Broad international historiography, which is only partially cited, as well as the rekindling of interest on the part of the previously cited Italian scholars, thrust its attention towards post-World War II, a period in which the combination of several factors, such as the emergence of the pervasive construction of the welfare state and a stronger influence of industrial relations, led to a profound transformation of Corporate Welfare ${ }^{7}$. Other equally important cases were added, such as the influence exercised by "Americanisation" ${ }^{8}$ on the whole European economy. From the perspective of management culture and its transformation, which occurred during the crucial years of the economic boom ${ }^{9}$, the adoption of Human Relations ('HR') had a significant influence in Italy. In addition to being widely debated, it was to impact with what had been donated by companies for a long time, and in many aspects shed more light on the nature of their actions. This is also to be

of Social History", Vol. XXVI, 191, pp. 255-301; an analytical in-depth study by the same author in J. MELLING, British Employers and Development of Industrial Welfare, c. 1880-1920: an industrial and Regional Comparison, Glasgow Ph D. 1980; for a more extended discussion see F. ROBERT, British Labour Management \& Industrial Welfare, Croom Helm, London 1988.

${ }^{5}$ The most significant studies on the overall experience of the U.S. and a significantly divergent interpretation of the nature and purpose of companies' social intervention: B. DAVID, Workers in Industrial America, New York 1980; S. D. BRANDES, American Welfare Capitalism 1880 - 1940, University of Chicago, Chicago 1970.

${ }^{6}$ For most recent historical revisionism in this field, see: J. SANFORD, Modern manors: Welfare capitalism since new deal, Princeton 1997; N. MANDELL, The Corporation as Family. The Gendering of Corporate Welfare, 1890-1930, University of North Carolina Press, Chapel Hill, 2002; T. ANDREA, The Business of Benevolence: Industrial Paternalism in Progressive America, Cornell University Press, Ithaca NY 1997; K. SLUYTERMAN, Corporate Social Responsibility of Dutch Entrepreneurs in the Twentieth Century, in "Enterprise \& Society", No. 2, June 2012.

${ }^{7}$ Despite its singularity, see Pirelli's case as a significant experience in V. VARINI, Welfare at Pirelli. From Its Origins to the Post -WWII, in H. BONIN - P. THOMES (eds.), Old Paternalism. New Paternalism. Post-Paternalism (19th-21st Centuries), P.I.E. Peter Lang, Brussels 2013.

${ }^{8}$ J. ZEITLIN - G. HERRIGEL (eds.), Americanization and its limits. Reworking US technology in post-war Europe and Japan, Oxford University Press, Oxford 2000; H. G. SCHRÖTER, Americanization of the European Economy. A compact survey in Europe since the 1880s, Springer, Dordrecht 2005.

${ }^{9}$ The dissemination of HR also found comparisons and significant "religious" analogies in contemporary American experience, (E. Fones-Wolf, K. Fones-Wolf, Religion, Human Relations, and Union Avoidance in the 1950s: The Electrical Industry’s Southern Strategy and Its Limits, in "Enterprise \& Society", No. 1 March 2012). 
understood within the broader process concerning the formation and affirmation of post-World War II "corporate cultures", marked by overseas and European contamination. ${ }^{10}$

HR originated in the US based on experiments conducted in 1924 at Hawthorne's Western Electric Company, aimed at measuring the productivity of some manufacturing departments. The results appeared somewhat discordant, highlighting how the human factor, which was not provided for in the then dominant Tayloristic approach, impacted on productivity. This led to entrusting Elton Mayo, a scholar from Harvard University, with further in-depth studies to better understand the causes which affected labour productivity. These are experiments from which the HR theory emerged which saw widespread dissemination in the 1940s and 1950s to also become a widely debated topic in Italy post-World War II. Although a precise confirmation of the human factor incidence was not found in subsequent verifications, the HR approach found a "cognitive consonance" which rendered it particularly suited to the economic climate of the post-war years. HR ideology proved controversial to the Tayloristic view in considering work as a mere production factor, as the former placed greater emphasis on the connection between the person, the role of the worker, the company and the consequent need to create a socially pleasant and harmonious working environment. Moreover, according to Mayo, HR would be able to overcome the risk of alienating an industrial society, by restoring a spirit of belonging to the business community. And finally, HR gives importance to those informal and collaborative relationships that permeate companies and which Taylorism tended to deny ${ }^{11}$.

A brief reference to the studies conducted by Mayo is useful to better understand what the relationships between HR and Corporate Welfare were originally. According to Mayo, HR falls within the more general theme of "Human problems of an Industrial Civilisation"12, centred on aspects relating to labour in modern factory organisations. Mayo’s observations on "Fatigue" as a distinctive aspect of work seem enlightening. Antecedents to his reflections originated from studies in Britain during World War I, where the war effort led to the intensification of industrial production: results obtained, which were considered to be lacklustre, led the Industrial Fatigue Research Board, a British government agency, to carry out special studies to understand the causes of poor performance in national industry. Investigations focused primarily on the understanding of

\footnotetext{
${ }^{10}$ By dealing with "production organisers", Sapelli showed how to "Italianise American sciences” in HR. This was used as an encouragement for the establishment of a "general [family-oriented] model for all businesses" which, according to the author, largely became established in the crucial decades post-World War II, (G. Sapelli, Economia tecnologia e direzione d'impresa in Italia, Turin1994, pp. 278-279).

${ }^{11}$ For the origins, timeframes and causes of HR dissemination see G. BONAZZI, Storia del pensiero organizzativo, Franco Angeli, Milan 1990, pp. 54-70.

12 E. MAYO, The Human problems of an Industrial Civilization, Murray Printing Company, Cambridge Massachusetts 1946.
} 
the elements influencing labour productivity and further examining the "nature of fatigue"13. Numerous research undertaken in the 1920s mainly focused on the implementation of the work function $^{14}$, while in Mayo's contrary opinion, the search for a "single discovery, the simple remedy, the one best way, had failed to materialise”. ${ }^{15}$ This dissatisfaction prompted the scholar to undertake research at the Western Electric Company, the results of which helped make him famous. The wellknown "Hawthorne Experiment”, from which the original HR core emerged, was undertaken by the same author who is recognised as being one of the "highest in a list of industrial institutions if the order in such list were determined by consideration of the worker and a real concern for his welfare"16.

In this analysis, in addition to remuneration which Mayo judged to be high, workers benefited from several other services such as a "restaurant”"17 and a special "hospital" manned by specialised staff ${ }^{18}$. Both were managed by a "personnel division” capable of grasping, in the twenty years prior to the experiments conducted by Mayo, any “symptom of discontent”.

This led him to state that the validity of his assessment on HR was traced from "a company which was definitely committed to justice and humanity in its dealing with workers” and capable of increasing "the general high morale", not otherwise verifiable in situations deemed to be of "low morale”. ${ }^{19}$ Since Mayo’s original formulations, HR became valid and therefore adoptable in companies engaged in corporate welfare, whose presence was, as stated clearly by Mayo, considered essential for adequate worker satisfaction and preliminary to the achievement of an efficient functioning of a productive organisation.

Although there are no consistent findings on the fundamentals of the relationship between "morale"20 and productivity, as advocated in HR, it proved to be particularly suited to meet the production changes introduced post-World War II, through the dissemination of production processes with higher integration and automation which led to a more intense rigidity of the production flow ${ }^{21}$, dictated by machining-time rather than by manual execution of tasks, and by overcoming individual piecework in favour of collective, team or departmental recognition. Thus,

\footnotetext{
${ }^{13}$ MAYO, The Human problems, p. 2.

14 "Hours of Work, Rest Pauses, Industrial Accidents, Atmospheric Conditions, Vision and Lighting, Vocational Guidance and Selection, Time and Movement Study, Posture and Physique”, (MAYO, The Human problems, p. 6).

${ }^{15}$ MAYO, The Human problems, p. 6.

${ }^{16}$ MAYO, The Human problems, p. 95.

17 "In which good food is obtainable at moderate prices", (MAYO, The Human problems, p. 95).

18 "Adequately equipped, and staffed by medical officers of high qualifications”, (MAYO, The Human problems, p. 95).

19 "In an industry of low morale and uncertain of its intentions, the inquiry would not have been possible", (MAYO, The Human problems, p. 96).

${ }^{20}$ The meaning of "Morale" appears to be similar to welfare in Mayo’s formulation, although the author simply defines it as "any accepted meaning of that term," (MAYO, The Human problems, p. 95).

${ }^{21}$ For automation processes in Italy see D. BIGAZZI, Modelli e pratiche organizzative nell'industria italiana, "Storia d'Italia. Annali 15. L'industria”, pp. 986-988.
} 
this also gave technological importance to HR as opposed to a mere ideological preference. With regard to the depersonalisation of production processes, it was therefore necessary to oppose the personalisation of hierarchical production relationships, insisting on the training of Heads called to become the main interlocutors with workers. Interventions which, however, were not going to radically change work performance, so much so that some were deemed to be a Taylorism ${ }^{22}$ "lubricating” technique.

Similar attitudes and reflections are found in the experience of Germany in the years preceding World War II, such as Siemens, where the pursuit of "technical and organisational rationalisations" led to the adoption of management policies aimed at "work motivation, training, integration, and commitment to the company”. These included intensive efforts in terms of corporate welfare. ${ }^{23}$

The objective of improving working conditions and seeking the involvement of workers in corporate life directly impacted on widespread welfare practices in Italian companies. In particular, HR placed critical emphasis on their "paternalistic" approach which had already been submitted to a thorough review due to the attempt to include it in trade union negotiations.

Its dissemination in Italy in the post-war "Americanisation”24 climate favoured by the Marshall $\operatorname{Plan}^{25}$, also depended on the work carried out by appropriate educational institutions dedicated to the spreading of management theories. These included the Post-graduate Institute of Business Administration (IPSOA) which was set up in Turin in 1952, where the training needs sought by Olivetti and Fiat ${ }^{26}$ were channelled, or in the Milan Institute for Training in Industry promoted by Pirelli, Edison, Montecatini and Falck.

Simultaneously, HR provoked broad reflection in Milanese employment where, especially among Catholics, "opposing” opinions emerged among the Christian Union of Enterpreneurs and Managers (UCID) and the Christian Associations of Italian Workers (ACLI). The former were in favour, while the latter denounced the "scandalous implications ... on the state of human relations in the

\footnotetext{
${ }^{22}$ BonAZZI, Storia del pensiero, p. 70.

23 "Expenditure for this 'social programme' were considerable ... and it was an element of the company's social engineering policy”, (H. Homburg, Scientific Management and Personnel Policy in the Modern German Enterprise, 1918-1939: The Case of Siemens, in H. F. GOSPER, C. R. LITTLER (eds.), Managerial Strategies and Industrial Relations. An Historical and Comparative Study, London, 1983, pp. 148-155).

${ }^{24}$ For the impact of Americanism, especially in relation to the productivity objectives of overseas contributions see J. McGlade, Uncle-Sam, Industrial-Engineer-Plan. America programme for productivity and economic-recovery in Western Europe (1948-1958), in “Historical Studies”, No. 1, January-March 1996.

${ }^{25}$ For the importance of the Marshall Plan in Italy’s post-World War II recovery, see the contributions in A. CovA (ed.), Il dilemma dell'integrazione. L'inserimento dell'economia italiana nel sistema occidentale 1945-1957), FrancoAngeli, Milan 2008.

${ }^{26}$ For the origins and objectives of the IPSOA, please refer to G. GEMELLI, Un esperimento in vitro: l'IPSOA di Torino (1952-1965), in G. GEMELLI (ed.), Scuole di management. Origini e sviluppo delle business schools in Italia, Il Mulino, Bologna 1997.
} 
factories of Lombardy” ${ }^{27}$ In this regard, it is worth noting Mario Romani's keen insights on the "reorganisation of company organisation", where the purpose was specified in the "meeting of workers' needs... [thus] to reduce or eliminate ... any situation contrary to a person's dignity”. This, in the perspective of promoting "a sense of employee belonging within the company", with the resulting "management responsibility" to be implemented through special representative "bodies", as an opportunity for the direct involvement of "trade unions". ${ }^{28}$

More generally, the above reflections can be placed within the debate on "productivity" which posed serious questions to all those involved, starting with employee representatives regarding their involvement in company management, also touching upon the very nature of the company and the responsibilities of all social stakeholders involved, as well as the distribution of benefits arising from the improvements obtained from the widespread use of innovations ${ }^{29}$.

Within the limits of the HR topic, critical opinions toward the intentions espoused by these approaches also came from those who had to foster their collaborative adoption within companies. An eyewitness, a manager at OSRAM in the early 1950s, complained that the conviction that workers were a mere "means of production and nothing more”30 lingered in the corporate culture. Thus, the adoption of HR generated opposing reflections among trade union members, with attitudes that favoured collaborative prospects on the part of the Italian Confederation of Workers' Trade Unions (CISL), while the Italian General Confederation of Labour (CGIL) maintained strong opposition $^{31}$; in addition, adversity was rife even within the Confindustria out of concern that

\footnotetext{
${ }^{27}$ On acceptance of HR and the value attributed to it in guiding employer and worker behaviour in companies see A. Ferrari, La civiltà industriale. Colpa e redenzione. Aspetti della cultura sociale in età degasperiana, Brescia, 1984, pp.105-106.

${ }^{28}$ M. Romani, I rapporti sociali nell'azienda, in Il risorgimento sindacale in Italia. Scritti e discorsi 1951-1975, S. Zaninelli (ed.), Milan 1988, pp. 69-71; for a total reconstruction of the debate within the CISL regarding the "active participation of all workers in managerial responsibilities" in the hope of "new company organisational criteria," capable of fully grasping the trends toward "humanisation" and to combat worker "depersonalisation" see V. Saba, Il problema storico della Cisl. La cittadinanza sindacale in Italia nella società civile e nella società politica (1950-1993), Rome, 2000, pp. 74-76.

${ }^{29}$ For issues relating to the company, innovation and the debate provoked by the establishment of the Italian National Productivity Committee see A. Carera, Progresso tecnico e organizzazione del lavoro nell'industria italiana (19501960), in "Annali Fondazione Pastore", 1993, in addition to contributions in the same volume of S. Chillè, A. Ferrari and G. Bianchi; for a European overview on "US Technical Assistance and Productivity Mission” see H. G. Schröter, Americanization of the European Economy, Dordrecht, 2005, pp. 50-53.

${ }^{30}$ A. MARzotTo CAOTORTA, Vita di fabbrica. La questione sociale vissuta a Milano e la scoperta delle relazioni umane: 1954-1964, Editrice Nuovi Autori, Milan 2006, p. 48.

${ }^{31}$ For the CGIL's position on HR as an expression of an "ideological agenda" or to "weaken the resistance" of the worker, see S. Leonardo, Relazione generale, p. 46 and B. TRENTIN, Produttività, relazioni umane, salario, p. 290, respectively; both in I lavoratori e il progresso tecnico, Editori Riuniti, Rome 1956; in general for CGIL intentions regarding the topics of work and enterprise see B. Trentin, Le dottrine neocapitalistiche e l'ideologia delle forze dominanti nella politica italiana, Rome, 1962; for an overview on the CGIL perspective on these matters see P. Ichino, Partecipazione dei lavoratori nell'impresa: le ragioni di un ritardo, in "Rivista Italiana di Diritto del Lavoro”, 4/2013.
} 
employers' freedom of decision would become limited ${ }^{32}$. The goal of improving working conditions and involvement in company life could not but influence the long-term social work granted by companies, revealing a conflicting reaction at the onset. Conflicting also when compared to the overseas experience where HR was closely related to the renewed intervention of companies in the field of welfare ${ }^{33}$.

The first and important moment of public reflection on HR in Italy occurred in April 1954 in Milan, where a national conference was held: "Le relazioni umane nell'industria" (Human relations in industry), sponsored by the Istituto di Studi sul Lavoro (Research Institute on labour), where the honorary committee, besides various known heirs of industrial dynasties such as Giovanni Falck and Alberto Pirelli, included the Minister of Industry and Commerce (Bruno Villabruna), the Minister of Finance (Roberto Tremelloni), the Minister of Labour (Ezio Vigorelli), Angelo Costa (President of Confindustria) and many other members of government and the business community, followed a year later by two other events. The first was held in Milan, in April, and the second in Stresa, in September. The Istituto di Studi sul Lavoro organised these initiatives, "having inherited from its predecessor, ENIOS, the task ... of working toward the technical and scientific progress of labour»34. ENIOS was the entity which, in previous decades, played a decisive role in the adoption of Tayloristic theories and practices in the Italian economy. ${ }^{35}$

In addition to the documents generated by these conferences, the reports published in three periodicals specifically dedicated to HR are useful: "Fattore Umano. Rivista mensile di direzione ed organizzazione aziendale per il periodo 1955-1961” (The Human Factor. Monthly review of management and company organisation for the period 1955-1961), followed by "Bollettino d'informazione per la direzione aziendale. Rapporto mensile a cura dell'Istituto per gli studi economici ed organizzativi (1962 - 1966)” (Information Bulletin for company management. Monthly report by the Institute for Economic and Organisational Studies [1962 - 1966]) and finally, "L'assistenza sociale nell'industria italiana. Rivista bimestrale della Confederazione generale

\footnotetext{
${ }^{32}$ For Confindustria's critical attitude toward the "participation" of workers in the management of the company, in particular, Angelo Costa's dissent on the direct involvement of employee representatives, see V. Saba, Scritti e discorsi di Angelo Costa, in "Lavoro e sindacato", No. 3, 1985, p. 17 and No. 4, 1985 ; F. Fauri, V. Zamagni (eds.), Angelo Costa un ritratto a più dimensioni, Bologna, 2007.

33 "Ford Motor Company began its management-financed recreation program in 1945 ... as representing a new and vigorous phase of the 'human relations' that we hear so much about these days”. (E. FonEs-WoLF, Industrial Recreation in the Second World War, and the Revival of Welfare Capitalism, 1934-1960, in Business History Review, Vol. 60, 2 (Summer, 1986), p. 254.

${ }_{34}$ Achille Marazza's speech in Le relazioni umane nell'industria. Atti del $1^{\circ}$ convegno nazionale. Milan - 27 April 1954, Istituto di Studi sul Lavoro, Rome 1954, p. 30.

${ }^{35}$ For the work performed by ENIOS, see G. SAPELLI, Organizzazione, lavoro e innovazione industriale in Italia tra le due guerre, Rosember \& Sellier, Turin 1978, pp. 49-52; D. BIGAZZI, Modelli e pratiche organizzative nell'industria italiana, "Storia d'Italia. Annali 15. L'industria”, pp. 942-943.
} 
dell'industria italiana (1964 - 1968)” (Social welfare in Italian industry. Bi-monthly journal of the Italian General Confederation of Industry [1964 - 1968]).

The crucial period in which HR attracted the most attention was between 1954 and 1960, the years where criticism and afterthoughts were raised with regard to its ability to achieve the goals pursued, so much so that the above-mentioned Bulletin shifted its attention from HR to business organisational and managerial aspects. Thus, it is possible to distinguish the development stages of attitudes towards HR. A general positive opinion on the prospect of overcoming conflict in favour of collaboration emerged at the onset. This was followed by a more pessimistic realism on the possibilities of a thorough change in industrial relations ${ }^{36}$.

With regard to social work, this was considered critical due to the risks of a "paternalistic" use, that is, the prevailing emphasis on the aspects of subordination between the company and the employee. A relationship that is clearly contrary to the founding assumptions of HR, so much so that the reports of the first conference in 1954 often included remarks that an employer adopting a paternalistic attitude in business relations will never succeed "jamais a créer un climat des relations humaines authentiques", to the extent that "il tolérera cet état de chose par une forme d'incoscience qui demeure une forme infantile de dépendance. Ou bien il sentira la morsure ciusante des humiliants bienfaits paternalistes accordés comme une aumône"37. Overcoming paternalism was necessary for a solid and sustained implementation of the desired collaboration. A "renewal in the

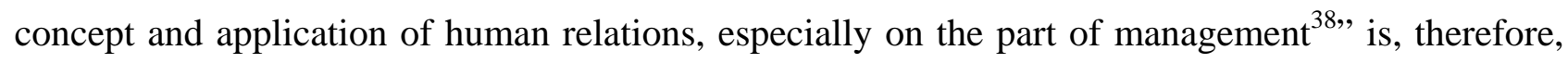
what was sought.

Unions also made the same inferences: paternalism is identified in the "employer's behaviour providing protection and unsolicited collective assistance to employees, conceived in terms of charity and with the aim of appeasing workers' consciences ... in order to get them to relinquish their demands"39.

Therefore, an essential point emerged relating to continuity in the provision of social work and welfare from companies. These became the subject of general contention, since they were considered to be a tool to reinforce the subordination of workers and contrary to the full assertion of

\footnotetext{
${ }^{36}$ For this pessimistic outlook, see the historiographic reflections in A. Accornero (ed.), Per una nuova fase di studi sul movimento sindacale, in "Annali della Fondazione Feltrinelli", 1976; similar approach taken by G. Petrillo, La capitale del miracolo. Sviluppo lavoro potere a Milano 1953 - 1962, Milan, 1992, pp. 144-150.

${ }^{37}$ J. SERIEX, Les obstacles majeurs aux relations humaines dans l'entreprise, in Atti del Convegno Internazionale su l'Organizzazione Umana nell'Economia industriale. Human Relations in Italia. Volume One, Edizioni CdA, Rome 1955, p. 120.

${ }^{38}$ V. Pons de WARtensee, Premessa, in Le relazioni umane nell'industria. Atti del $1^{\circ}$ convegno nazionale. Milan - 27 April 1954, Istituto di Studi sul Lavoro, Rome, 1954, [p. 18].

${ }^{39}$ Speech by Pasquale Valsecchi, Secretary CISL - Como, in Atti del Convegno Internazionale su l'Organizzazione Umana nell'Economia industriale. Human Relations in Italia. Volume One, Edizioni CdA, Rome 1955, p. 420.
} 
the worker's personality. However, these concrete considerations were dropped, wherein corporate welfare, in its many forms, was a consolidated act of companies.

At the same time the need, as expressed by union representatives, to regulate welfare through negotiation became more evident, removing it from the discretion of the employer and company management ${ }^{40}$.

Terms such as “consent”, “collaboration”, and “participation” increasingly contrasted terms such as “dictatorship" and "minority”, which were considered instead to be "paternalistic" attributes. Operational forms were proposed that were intended to pursue collaboration through "communication and training", where the former dealt with interaction methods between hierarchies, characterised by a two-way flow and a growing role of intermediate figures. The message was intended as a prerequisite to participation, and to this end, "suggestion boxes"41 and "company newsletters" ${ }^{42}$ were proposed. For training, the focal point was that "the training of

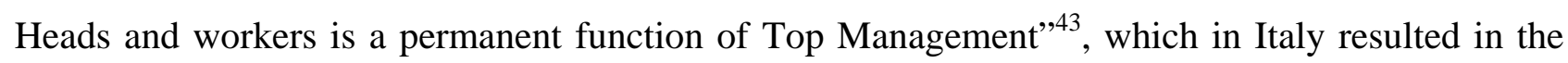
Training Within Industry (TWI), that is, the “ability to lead ... the Head's ability to obtain employee collaboration" ${ }^{44}$.

With regard to the latter practices, the training "of Heads", as mentioned earlier, deserves a brief mention. It was promoted within individual companies and aimed at “employment relations.” Some examples may better clarify the meaning and also the connections with their social intervention.

At OM in Brescia ${ }^{45}$, training "courses" devoted to "employment relations" were mainly reserved for "Heads" and mostly confirmed the need to obtain the "collaboration" of skilled workers. ${ }^{46}$ Heads were chosen from those who undertook "delegation of authority" in the management of “production” employees and their task consisted of exercising a controlling influence based on

\footnotetext{
${ }^{40}$ For Olivetti's "confrontational" experience, see S. Musso, La partecipazione nell'impresa responsabile. Storia del Consiglio di Gestione Olivetti, Il Mulino, Bologna 2009, especially pp. 124-126.

${ }^{41}$ A. TOMASI, Un esempio di applicazione del sistema dei suggerimenti del personale, "Fattore Umano. Rivista bimestrale di direzione aziendale", 1959, pp. 544-550; the example cited refers to Ansaldo where in the five years between 1954 - 1959, there were 10,621 registered proposals and 2,836 awarded amounting to a total of 7,375,650 Lire (TOMASI, An example of, p. 546).

${ }^{42}$ Luci ed ombre dei giornali aziendali, "Bollettino d'informazione per la direzione aziendale”, 3 December 1962; while for a comprehensive overview on the house organ published post-World War II, see G. BIGATTI - C. VINCI (eds.), Cultura e strategie dell'immagine nell'industria italiana (1945-1970), Guerini e Associati, Milan 2010.

${ }^{43}$ L. di Colloredo, Considerazioni su Stresa, "Fattore umano. Rivista di direzione e organizzazione aziendale", December 1955, p. 6.

${ }^{44}$ Speech by Umberto Baldini in Le relazioni umane nell'industria. Atti del $1^{\circ}$ convegno nazionale. Milan - 27 April 1954, Istituto di Studi sul Lavoro, Rome 1954, p. 77.

${ }^{45}$ For some indications on company origins and development, see: OM, una storia nella storia, Edizioni Negri, Brescia, 1991.

46 "You can pay a man to work; but his enthusiasm, his initiative, his loyalty and his collaboration are things that one must learn how to earn, and day by day”, (OM. Guida per i capi. Quaderno N. 1. Compendio del corso per le relazioni del lavoro, Brescia 1955).
} 
authority derived from the hierarchy and from the active participation of subordinates. ${ }^{47}$ It is precisely the latter which imposed an "interest in their life and working conditions”,48, by evoking social intervention practiced at the time, and always anchoring it to the priority interest of "production". 49 The declamation on the "method of dealing with problems" followed, which was more pronounced when the "Head" intervened to resolve the daily tasks arising from his role ${ }^{50}$. While not formally explicit and only schematically represented, the link with corporate welfare appeared where representation assumed its use in the governance of human relations.

Figure 1: Company “Heads”

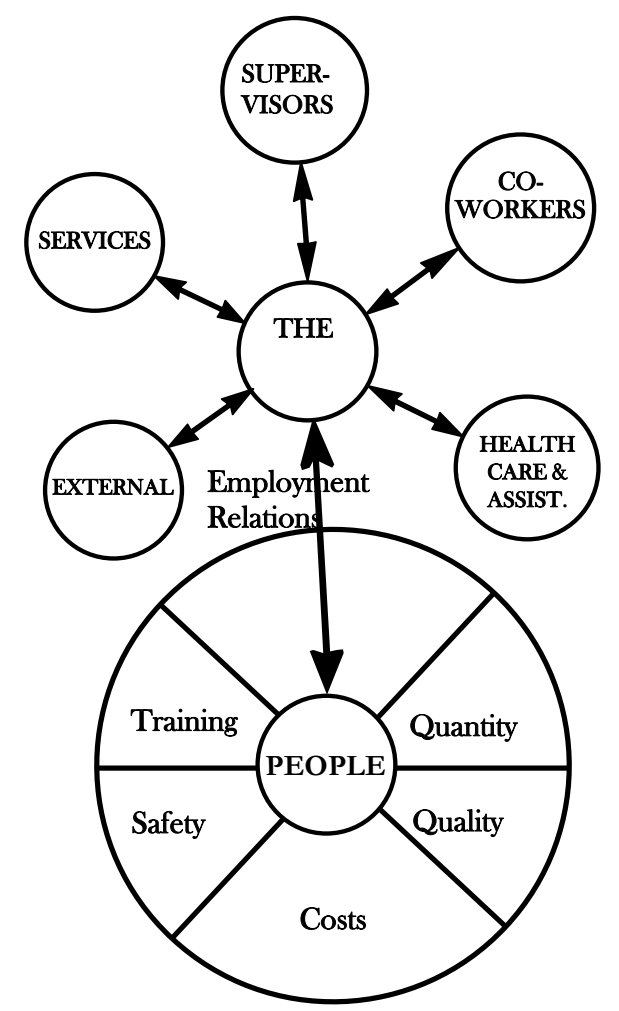

These relationships undoubtedly have an important impact on production, and consequently, on all the Company.

\footnotetext{
47 "A good leader knows how to manage well when he is capable of voluntarily obtaining from employees, the desired job at the desired time and in the manner in which it must be done ... a leader does not obtain results if not with the help of other men", (OM. Guida per i capi, pp. 5, 8); for the "sense" of authority and voluntary acceptance in "relationships between people", see R. Sennet, Autorità. Subordinazione e insubordinazione: l'ambiguo vincolo tra il forte e il debole, Milan, 1980.

${ }^{48}$ OM. Guida per i capi, p.11.

49 "The fundamental objective to always bear in mind with the utmost clarity is that of production" (OM. Guida per $i$ capi, p. 17).

${ }^{50}$ These phases represented training: "gather facts ... weigh and decide ... take action ... check the results," (OM. Guida per i capi, pp. 17 - 20).
} 
Source: OM. Guida per i capi. Quaderno N. 1. Compendio del corso per le relazioni sul lavoro, Brescia 1955, p. 23 (OM. Leaders' Manual. Book No. 1. A compendium of the course on employment relations).

Another significant case is related to Falck, a company that was widely studied due to the extent of its social intervention. Characterised by an extensive presence in its various operating locations Arcore, Dongo, Sesto San Giovanni and Vestone - it came to cover the full range of social services and welfare, aimed at both the individual worker as well as the needs of the whole community around the factories. ${ }^{51}$

With regard to "special training courses on human relations within the company," these commenced in 1954; they confirmed the same aspects mentioned above, such as the involvement of those who were "vested with leadership functions" and provided specific attention to "working methods" which were designed to improve productivity results. ${ }^{52}$

Participation reached reasonable levels of involvement with more than eight hundred employees out of a total of approximately $15,000^{53}$ in the first year alone. The same terms found at $\mathrm{OM}$ also resumed at Falck, such as "cordiality and collaboration", as the necessary ingredients for the actual implementation of production programmes pursued by the company. ${ }^{54}$ The relationship between "the Head and employees" increasingly became the metaphor of the company. This was based on "mutual trust that results in a successful collaboration between all staff". ${ }^{55}$ Instructions on the behaviours to be adopted in order to improve leadership skills followed, with no juxtaposition to Falck's welfare which, post-World War II saw an expansion in the organisational dimension with the adoption of an "assistance service". This was entrusted to a "staff complement of some 10 assistants," formed by the "School of Social Services "operating in Milan, and where Enrico Falck was one of the founders. ${ }^{56}$ Albeit limited to the narrow confines of HR, they lost relevance in

\footnotetext{
${ }^{51}$ For a comprehensive overview of welfare and social security in addition to the extensive speech dedicated to leisure time, for Falck see, L. TrezzI, Le "provvidenze sociali", in Le famiglie industriali lombarde: Falck, rinnovamento nella continuità, UCID, Milan 2005, pp. 93-106; for an overview of social welfare at Falck and neighbouring large companies operating in the industrial centre of Sesto San Giovanni, see V. VARINI, Impresa, enti locali, welfare company in Lombardia. Intervento municipale e iniziativa privata tra XIX e XX secolo, Franco Angeli, Milan 2012, pp. 179-181.

52 “Corsi speciali di addestramento sulle relazioni umane nell'impresa”, La Ferriera, 30 June 1954, p. 2, with similar analogies on the definition of "good leader ... job knowledge ... knowledge of responsibilities ... ability to manage... ability to instruct ... ability to improve working methods" ("Corsi speciali di addestramento sulle relazioni umane nell'impresa III ${ }^{\circ}$, La Ferriera, 30 September 1954, p. 2).

${ }^{53}$ V.VARINI, La metamorfosi industriale: dalla città delle fabbriche all'impresa diffusa, in L. TREZZI (eds.), Sesto San Giovanni 1953-1973. Economia e società: equilibrio e mutamento, Skira, Milan 2007, p. 190.

54 “Corsi speciali di addestramento sulle relazioni umane nell'impresa”, La Ferriera, 23 August, 1954, p. 6.

55 “Corsi speciali di addestramento sulle relazioni umane nell'impresa IV”, La Ferriera, 10 December 1954, p. 8; for relationships between "reciprocity" and "dependence", see R. Sennet, Rispetto. La dignità umana in un mondo di diseguali, Bologna, 2003.

56 “Compie quindici anni di vita la Scuola di servizio sociale”, La Ferriera, May 1960, p. 14.
} 
subsequent years, at least in the printing of company chronicles, while references to the "responsibility for the lives of all families alongside these men [workers]" remained, emphasising the social nature of the company based on the satisfaction of the needs of the whole community in which it operated. ${ }^{57}$

Notwithstanding the two tools of communication and training, some HR incentives were proposed. The HR and social work connection became the subject of critical reflection so that the actual application in companies underwent a significant transformation and was reflected in the change in corporate welfare during the period.

As mentioned previously, a sceptical attitude prevailed, characterised by a distancing from the provision of welfare assistance which was deemed to be paternalistic and likely to result in the criticism of welfare provision being interpreted as an indicator of a worker's subordination. The issue was expressed in quite simple terms: if social work is the outcome of a unilateral donation, this had to stop because it was contrary to the spirit advocated by HR. It could only be included in a proper relationship with workers if it was free of any reference to paternalism. It therefore became vitally important and essential to adopt measures which neutralised the alleged paternalistic component in order to maintain welfare.

Two opposing testimonies can be reported on the conflicting positions regarding the importance of HR: one favoured the removal of corporate welfare; the other was more receptive to the spreading of welfare practiced by the national industry.

Carlo Bobbio, Chief Executive Officer of Edison, put it this way: "a human relations policy is difficult to reconcile with an extensive use of activities that prove to be counterproductive, with the aim of fostering a sense of responsibility and initiative in the worker ... it would be preferable to avoid a top-down predetermined approach to satisfy certain needs" ${ }^{\text {"58 }}$ and, as an alternative to corporate welfare, suggested the pursuit of a policy of "good wages as being the most favourable condition for the development of a policy of good human relations ... [also] it prevents the company from engaging in excessive activities of a welfare nature”59. This was a stance that was also taken by some trade union leaders who proposed the abandonment of social work because this was the glue of the business community, generating the identification of workers with their own company. Both positions agreed with the proposal to abandon welfare projects, delegating them to external

\footnotetext{
57 "The company is a complex that is emerging as a human community ... for which everyone assumes responsibility, precisely because this community fulfils a purpose which transcends that of the company", ("Concluso con successo a Sesto il corso unico UCID per capi maestranza”, La Ferriera, November 1960, No. 7, p. 11).

${ }^{58}$ A speech by Carlo Bobbio in Le relazioni umane nell'industria. Atti del $1^{\circ}$ convegno nazionale. Milan 27 April 1954, Istituto di Studi sul Lavoro, Rome 1954, p. 61.

${ }^{59}$ Le relazioni umane nell'industria, p. 61.
} 
agencies with no company affiliation, thus emphasising the prevalent and unique, productive purpose of the enterprise.

Given these radical attitudes which became a minority over time, there was a more conciliatory interpretation which, in the words of Alberto Boyer, Director of Ansaldo of Genoa, "we are forced to strip the welfare service of any paternalism ... which adversely affects welfare ... of a gift from the company which may affect the susceptibility of workers.” Instead, he proposed making a distinguishment through an effective comparison: "doing it without, is paternalism" while "doing it with, makes for healthy human relationships and collaboration” ${ }^{\prime 0}$. Social work became valuable “adjoining” support to HR.

A further confirmation of this transformation occurred in the second national conference dedicated to HR, where it was explicitly mentioned how HR was founded on a shared "identity" ${ }^{61}$ from which emerged a precise role of personnel management: "vocational education, morale and the psychology of workers ... delivery of social, welfare and recreational services”. ${ }^{2}$

The question on how to eliminate the paternalistic nature of social work remained open.

In this sense, the "General Confederation of Italian Industry ... believes that social workers can be very useful in various sectors of the business by working directly with executives and middle managers in the search for solutions that will help to improve human relations and the protection of workers' personality" ${ }^{\prime 63}$. Social workers were required to boost the worker's confidence and esteem in corporate hierarchies. Their mediation had to overcome those practices that were deemed by representatives of the industrial vanguards to be of "constant mortification or humiliation for workers with every concession made outside of the contractual relationship", whereas the social worker had to act towards boosting the "worker's personality"64.

The debate continued with concrete examples of the service provided by social workers in two known enterprises: the first, a subsidiary of Unilever; the other, Pirelli. In the first case, the social welfare service was set up in 1961 and managed by a "graduate” social worker independent of other management to facilitate contact with the workers. His tasks were to accept requests for intervention from workers to promote "the integration of the individual in the work community".

\footnotetext{
${ }^{60}$ Speech by Achilles Marazza, President of the Istituto di Studi sul Lavoro in Le relazioni umane nell'industria. Atti del $1^{\circ}$ convegno nazionale. Milan 27 April 1954, Istituto di Studi sul Lavoro, Rome 1954, p.27.

61 "The type of human relations policy envisaged by us is one where there is an area of identity, a connecting point between the basic interests of the employer and those of the worker", speech by Umberto Balsini, Head of Personnel of Montecatini, in La direzione del personale. Atti del secondo convegno nazionale per le relazioni umane nelle industrie, Istituto di Studi sul Lavoro, Rome 1955, p. 40.

${ }^{62}$ Speech by Mario Fasciano, Personnel Manager of Innocenti, La direzione del personale, p. 47.

63 "I Sindacati e la Confindustria di fronte al servizio sociale di fabbrica", Notizie Olivetti, No. 74, March 1962; see also E. MARConcini, Servizio sociale e industria, "L'assistenza sociale nell'industria italiana”, July-August 1966, pp. 25-27.

64 "Convegno di studi sull'assistenza sociale di fabbrica", L'assistenza sociale nell'industria italiana, January-February 1964, pp. 28-30.
} 
Moreover, his assistance extended to the family unit. Intervention methods included face-to-face dialogue, reporting problems to the "Head" of personnel and finally, reporting to the health care service.

In the case of Pirelli, the journal "L'Assistenza sociale nell'industria italiana" ("Social Welfare in Italian Industry”) carried the annual report prepared by those responsible for social welfare in the Pirelli Group. The service addressed three distinct areas: the first was related to individual employees for problems of a psychological and social nature connected to their presence in the corporate community and family relationships ${ }^{65}$; the second dealt with new recruits, to foster integration in the company through an illustration of the company's characteristics and presenting the welfare service as the interlocutor for all problems related to the daily work routine ${ }^{66}$; while the third acted on corporate structures, that is, it discussed the role of dialogue among middle managers, senior management and employees ${ }^{67}$. And, to summarise Pirelli’s welfare service, a concrete application was shown at one of its Italian factories at Arco Felice, in the province of Naples. ${ }^{68}$ Another important example concerns the Società Elettrica Piemontese (Piedmontese Electric Company), where extensive social work ${ }^{69}$ found its coagulant in the aid provided which was capable of managing the entire network of production units scattered throughout a wide area. ${ }^{70}$

Always at the suggestion of Confindustria, assistants had hoped to be entrusted with working men's clubs, with the explicit goal of strengthening the ties of belonging to the business community ${ }^{71}$. In addition to social welfare, there was also a recognition of needing to overcome the "mistrust of

\footnotetext{
65 "The problems that usually cause an employee to contact the social worker are of a psychological and social nature and the most frequently recurring situations are those relating to dissatisfaction or maladjustment in the family or work, or are related to subnormal childrens' education or misconduct, ("Riunione annuale delle assistenti sociali del gruppo Pirelli”, L'assistenza sociale nell'industria italiana, May-August 1968, p. 69).

66 "The purpose of a social worker is: to present corporate resources (educational assistance, educational refresher courses, retirement homes, cultural activities, sports activities, different practices, counselling for injuries outside of work, the suggestion box ... Piero Pirelli Vocational Institute ("Riunione annuale delle assistenti sociali del gruppo Pirelli”, L'assistenza sociale nell'industria italiana, May-August. 1968, p. 72).

67 "Activities ... intended to ensure that social service is better known, perceived and used as a staff service, and to communicate the fundamental views and needs for the purposes of adapting to them ... corporate social services" ("Riunione annuale delle assistenti sociali del gruppo Pirelli", L'assistenza sociale nell'industria italiana, May-August 1968, p. 72).

${ }^{68}$ As a measure of the size of Pirelli's welfare in 1951, the "health" unit alone consisted of: 685 contractual doctors, including 616 general practitioners and 69 specialists (6 of whom in the Bicocca outpatient clinic); 12 home carers; 73 affiliate hospitals; 20 clinics for special treatments, 680 pharmacies, (25 anni di Assistenza Sanitaria, "Fatti e notizie. Periodico interno della Pirelli S.p.A di Milano", 10 (1951).

69 "Montessori Kindergarten, summer camps for children, scholarships, vocational training courses, legal and tax advice, very modern sanitary facilities, individual contributions, etc.", (speech by Caterina Ruschena Migliasso in La direzione del personale, p. 148).

70 "SIP employees are stationed in diverse locations due to business needs: external offices, power stations, dams and mountain basins. Our social welfare reaches everywhere and in the past year, its intervention was required in around 400 cases: granting of loans, housing problems, visits to sanatoriums and hospitals, children's admission to boarding school, practices at offices and external institutions, assistance to road accident victims and their families", (speech by Caterina Ruschena Migliasso in La direzione del personale, p. 148).

${ }^{71}$ On the origins and dissemination of working men's clubs, see V. DE GRAZIA, Consenso e cultura di massa nell'Italia fascista. L'organizzazione del dopolavoro, Laterza, Rome, Bari 1981.
} 
workers who accuse employers of ulterior political motives ... a neutral element was needed to achieve a spiritual balance between employer and employee”72 and welfare disbursements were identified as the best tool to "eliminate situations of shortage or need, but above all, to raise the cultural tone”. In this perspective, where mediation was performed by the social worker, social work would have lost its much-criticised paternalistic character. In the same words of the leaders of the Confindustria associations, welfare was "the connective tissue of all the initiatives and corporate services of a social nature in favour of employees: summer camps for children, scholarships, cultural and recreational activities" ${ }^{, 73}$. The report of the Istituto per il Servizio Sociale di Fabbrica (the Institute for Factory Social Services) of Milan especially emphasised how " the collaboration of social workers for the functioning of corporate social work had been very useful»74.

Table 1. Factory social workers (1961 - 1968)

\begin{tabular}{|l|l|l|l|l|l|l|l|l|}
\hline & 1961 & 1962 & 1963 & 1964 & 1965 & 1966 & 1967 & 1968 \\
\hline Company employees & 158 & 170 & 271 & 297 & 295 & 276 & 273 & 270 \\
\hline $\begin{array}{l}\text { Employees from the offices } \\
\text { of industrial associations }\end{array}$ & 81 & 81 & 72 & 74 & 68 & 63 & 62 & 61 \\
\hline $\begin{array}{l}\text { Employees from specialized } \\
\text { institutions }\end{array}$ & 319 & 450 & 587 & 585 & 599 & 556 & 557 & 563 \\
\hline Freelance professionals & 24 & 46 & 67 & 68 & 68 & 25 & 25 & 25 \\
\hline Factory social workers & 582 & 747 & 997 & 1024 & 1030 & 920 & 917 & 919 \\
\hline
\end{tabular}

Source: Il servizio sociale di fabbrica, Arti Grafiche, Rome 1969 (Documentation in the Review “Iniziative Sociali dell'Industria Italiana (Social initiatives of Italian Industry)”, Supplement No. 5, 1969, p. 59).

In conclusion, social work is an essential component of the practices adopted by companies for the building and strengthening of communities. From an HR perspective, this enabled the building of relations even after working hours by maintaining solid ties during leisure activities and through services for the worker's family members. The social worker had to intervene and act as a mediator in order to avoid a more direct and criticised hierarchical distribution of benefits.

\footnotetext{
72 "Today, this is considered to be an instrument of corporate solidarity and educational action that tends to not only improve the moral conditions of individual workers, but also the human relationships within the working environment", (R. PAOLONI, Fattore umano e servizio sociale di fabbrica, "L'assistenza sociale nell'industria italiana”, March-April 1964, p. 27).

73 “Incontro di studio per assistenti sociali di fabbrica promosso dall'E.V.A.S.”, L'assistenza sociale nell'industria italiana, July-October 1967, p. 78.

${ }^{74}$ Il servizio sociale di fabbrica, Arti Grafiche, Rome 1969 (Notebooks of documentation in the Journal Rivista Iniziative Sociali dell'Industria Italiana, Supplement No. 5, 1969), p. 36.
} 
A verification of the effective operation of these figures is lacking which, in their supposed neutrality, on the one part, risks nullifying the original significance of social work and, on the other, of entering into competition and conflict with employee representatives. This has to do with proceeding, in light of the above considerations, to a more analytical verification of factory experiences, in order to verify the real impact as well as the persistence over time. However, the analysis undertaken observes how original nineteenth-century paternalism, in the changing forms adopted during the twentieth century, remains the constitutive factor of companies, permitting them to function in the reciprocity of relationships among the "human resources" that they underpin. 


\section{Bibliography}

Accornero A. (ed.) 1976: "Per una nuova fase di studi sul movimento sindacale”, Annali della Fondazione Feltrinelli. Andrea T. 1997: The Business of Benevolence: Industrial Paternalism in Progressive America, Ithaca NY, Cornell University Press.

Atti del Convegno 1955: Atti del Convegno Internazionale su l'Organizzazione Umana nell'Economia industriale. Human Relations in Italia. Volume Primo, Rome, Edizioni CdA.

Battilani P., Benassi C. (eds.) 2013: Consumare il welfare. L'esperienza italiana del secondo Novecento, Bologna, Il Mulino.

Bigazzi D. 1999: “Modelli e pratiche organizzative nell'industria italiana”, Storia d'Italia. Annali 15. L'industria.

Bonazzi G.1990: Storia del pensiero organizzativo, Milan, Franco Angeli.

Brandes S. D.1970: American Welfare Capitalism 1880 - 1940, Chicago, University of Chicago Press.

Carera A. (ed.) 2009: Opere sociali e responsabilità d'impresa. Casi e temi nel Novecento, Milan, Vita \& Pensiero.

Carera A. 1993: "Progresso tecnico e organizzazione del lavoro nell'industria italiana (1950-1960)", Annali Fondazione Pastore.

Colloredo di L. 1955: “Considerazioni su Stresa”, Fattore umano. Rivista di direzione e organizzazione aziendale, December.

Convegno 1964: “Convegno di studi sull'assistenza sociale di fabbrica”, L'assistenza sociale nell'industria italiana, January February.

Cova A. (ed.) 2008: Il dilemma dell'integrazione. L'inserimento dell'economia italiana nel sistema occidentale 19451957), Milan, Franco Angeli.

David B. 1980: Workers in Industrial America, New York, Oxford University Press.

De Grazia V. 1981: Consenso e cultura di massa nell'Italia fascista. L'organizzazione del dopolavoro, Roma Bari, Laterza.

Fauri F., Zamagni V. (eds.) 2007: Angelo Costa un ritratto a più dimensioni, Bologna, Il Mulino.

Ferrari A. 1984: La civiltà industriale. Colpa e redenzione. Aspetti della cultura sociale in età degasperiana, Brescia, Morcelliana.

Fones E., Wolf K. 2012: “Religion, Human Relations, and Union Avoidance in the 1950s: The Electrical Industry’s Southern Strategy and Its Limits”, Enterprise \& Society, 1, March.

Fones-Wolf E. 1986: "Industrial Recreation in the Second World War, and the Revival of Welfare Capitalism, 19341960”, Business History Review, 2, summer.

G. Bigatti , C. Vinci (eds.) 2010; Cultura e strategie dell'immagine nell'industria italiana (1945-1970), Milan, Guerini e Associati.

Gemelli G. 1997: “Un esperimento in vitro: l'IPSOA di Torino (1952-1965)”, in G. Gemelli (ed.), Scuole di management. Origini e sviluppo delle business schools in Italia, Bologna, Il Mulino.

Homburg H. 1983: "Scientific Management and Personnel Policy in the Modern German Enterprise, 1918-1939: The Case of Siemens”, H. F. Gosper, C. R. Littler (eds.), Managerial Strategies and Industrial Relations. A Historical and Comparative Study, London, Heinemann Educational Books.

Ichino P. 2013: “Partecipazione dei lavoratori nell'impresa: le ragioni di un ritardo”, Rivista Italiana di Diritto del Lavoro, 4.

Il servizio sociale, 1969: Il servizio sociale di fabbrica, Arti Grafiche, Rome, 1969

Joyce P. 1984a: “Labour, capital and compromise: a response to Richard Price”, Social History, 1, January.

Joyce P. 1984b: "Languages of reciprocity and conflict: a further response to Richard Price”, Social History, 2, May.

La direzione del personale, 1955: La direzione del personale Atti del secondo convegno nazionale per le relazioni umane nelle industrie, Rome, Istituto di Studi sul Lavoro.

Le relazioni umane 1954: Le relazioni umane nell'industria. Atti del $1^{\circ}$ convegno nazionale. Milan - 27 April 1954, Istituto di Studi sul Lavoro, Rome.

Leonardo S. 1956: “Relazione generale”, I lavoratori e il progresso tecnico, Rome, Editori Riuniti.

Mandell N. 2002: The Corporation as Family. The Gendering of Corporate Welfare, 1890-1930, Chapel Hill, University of North Carolina Press.

Marconcini E. 1966: “Servizio sociale e industria”, L'assistenza sociale nell'industria italiana, July-August.

Marzotto Caotorta A. 2006: Vita di fabbrica. La questione sociale vissuta a Milano e la scoperta delle relazioni umane: 1954-1964, Milan, Editrice Nuovi Autori.

Mayo E. 1946: The Human problems of an Industrial Civilization, Cambridge Massachusetts, Murray Printing Company.

McGlade J. 1996: “Lo zio Sam ingegnere industriale. Il programma americano per la produttività e la ripresa economica dell'Europa occidentale (1948-1958)”, Studi storici, 1, January-March.

Melling J. 1980: British Employers and Development of Industrial Welfare, c. 1880-1920: an industrial and Regional Comparison, Glasgow Ph D. 
Melling J. 1991: "Employers, Industrial Housing, and the Evolution old company Welfare Policies in Britain' Heavy Industry: West Scotland, 1870-1920”, International Review of Social History, Vol. XXVI.

Musso S. 2009: La partecipazione nell'impresa responsabile. Storia del Consiglio di Gestione Olivetti, Bologna, Il Mulino.

OM, una storia 1991: OM, una storia nella storia, Brescia, Edizioni Negri.

OM. Guida 1955: OM. Guida per i capi. Quaderno N. 1. Compendio del corso per le relazioni del lavoro, Brescia.

Paoloni R. 1964: "Fattore umano e servizio sociale di fabbrica”, L'assistenza sociale nell'industria italiana, March.

Petrillo G. 1992: La capitale del miracolo. Sviluppo lavoro potere a Milano 1953 - 1962, Milan, Franco Angeli.

Pons de Wartensee V. 1954: "Premessa”, Le relazioni umane 1954.

Price R. 1983: “The labour process and labour history”, Social History, 1, January.

Price R. 1984: "Conflict and co-operation: a reply to Patrick Joyce”, Social History, 2, May.

Robert F. 1988: British Labour Management \& Industrial Welfare, London, Croom Helm.

Romani M. 1988: “I rapporti sociali nell'azienda”, S. Zaninelli (ed.) Il risorgimento sindacale in Italia. Scritti e discorsi 1951-1975, Milan, Franco Angeli.

Saba V. 1985: "Scritti e discorsi di Angelo Costa”, Lavoro e sindacato, 3/4.

Saba V.2000: Il problema storico della Cisl. La cittadinanza sindacale in Italia nella società civile e nella società politica (1950-1993), Rome, Edizioni Lavoro.

Sanford J. 1997: Modern manors: Welfare capitalism since new deal, Princeton, Princeton University Press.

Sapelli G. 1978: Organizzazione, lavoro e innovazione industriale in Italia tra le due guerre, Turin, Rosember \& Sellier.

Sapelli G. 1994: Economia tecnologia e direzione d'impresa in Italia, Turin, Einaudi.

Schröter H. G. 2005: Americanization of the European Economy. A compact survey in Europe since the 1880s, Dordrecht, Springer.

Schröter H.G. 2005: Americanization of the European Economy, Dordrecht, Springer.

Sennett R. 2003: Rispetto. La dignità umana in un mondo di diseguali, Bologna, Il Mulino.

Sennett R. 2008: Autorità. Subordinazione e insubordinazione: l'ambiguo vincolo tra il forte e il debole, Milan, Bruno Mondadori.

Seriex J. 1955: “Les obstacles majeurs aux relations humaines dans l'entreprise”, Atti del Convegno 1955.

Sluyterman K. 2012: “Corporate Social Responsibility of Dutch Entrepreneurs in the Twentieth Century”, Enterprise \& Society, Vol. 12, June

Tomasi A. 1959: "Un esempio di applicazione del sistema dei suggerimenti» del personale”, Fattore Umano. Rivista bimestrale di direzione aziendale, June.

Trentin B. 1992: "Le dottrine neocapitalistiche e l'ideologia delle forze dominanti nella politica economica italiana”, Politica ed economia, 3-4.

Trentin B. 1956: "Produttività, relazioni umane, salario”, I lavoratori e il progresso tecnico, Rome, Editori Riuniti.

Trezzi L. 2005: "Le "provvidenze sociali", Le famiglie industriali lombarde: Falck, rinnovamento nella continuità, Milan, UCID.

Trezzi L., Varini V. (eds.) 2012: Comunità di lavoro. Le opere sociali delle imprese e degli imprenditori tra Ottocento e Novecento, Milan, Guerini e Associati.

Varini V. 2007: “La metamorfosi industriale: dalla città delle fabbriche all'impresa diffusa”, L. Trezzi (ed), Sesto San Giovanni 1953-1973. Economia e società: equilibrio e mutamento, Milan, Skira.

Varini V. 2012: Impresa, enti locali, welfare company in Lombardia. Intervento municipale e iniziativa privata tra XIX e XX secolo, Milan, Franco Angeli.

Varini V. 2013: "Welfare at Pirelli. From Its Origins to the Post-WWII”, H. Bonin - P. Thomes (eds.), Old Paternalism. New Paternalism. Post-Paternalism (19th-21st Centuries), Bruxelles, P.I.E. Peter Lang.

Zeitlin J., Herrigel G. (eds.) 2000: Americanization and its limits. Reworking US technology in post-war Europe and Japan, Oxford, Oxford University Press. 